\title{
Tumor-associated fibroblast-conditioned medium induces CDDP resistance in HNSCC cells
}

\author{
Teresa Bernadette Steinbichler ${ }^{1}$, Veronika Metzler ${ }^{1}$, Christian Pritz $^{1}$, Herbert \\ Riechelmann ${ }^{1}$ and Jozsef Dudas ${ }^{1}$ \\ ${ }^{1}$ Department of Otorhinolaryngology, Medical University of Innsbruck, Innsbruck, Austria \\ Correspondence to: Teresa Bernadette Steinbichler, email: teresa.steinbichler@tirol-kliniken.at \\ Keywords: epithelial to mesenchymal transition, chemoresistance, cisplatin, cancer-associated fibroblasts, TGF- $\beta 1$ \\ Received: May 20, $2015 \quad$ Accepted: October 09, $2015 \quad$ Published: October 20, 2015
}

This is an open-access article distributed under the terms of the Creative Commons Attribution License, which permits unrestricted use, distribution, and reproduction in any medium, provided the original author and source are credited.

\section{ABSTRACT}

Objective: EMT (epithelial to mesenchymal transition) contributes to tumor progression and metastasis. We aimed to investigate the effects of EMT on CDDP resistance in HNSCC (head and neck squamous cell carcinoma)-cells.

Methods: EMT was induced using conditioned medium from a tumor cell/fibroblast co-culture. HNSCC cells were alternatively treated with TGF- $\beta 1$. The response to CDDP was evaluated with viability and clonogenic assays.

Results: Treatment of SCC-25/ Detroit 562 cells with conditioned medium increased viability of the tumor cells. Moreover, it doubled the IC $_{50}$ of CDDP of SCC-25 cells from $6.2 \mu \mathrm{M}$ to $13.1 \mu \mathrm{M}(p<0.001)$. The IC $_{50}$ of CDDP of Detroit 562 cells was increased following treatment with conditioned medium from $13.1 \mu \mathrm{M}$ to $26.8 \mu \mathrm{M}(p<0.01)$. Colony forming ability after treatment with 5 or $10 \mu \mathrm{M}$ CDDP was significantly higher in HNSCC cells treated with co-culture conditioned medium than in controls $(p<0.05)$. Treatment with TGF- $\beta 1$ had no effect on the $\operatorname{IC}_{50}$ of CDDP $(p>0.1)$.

Conclusions: Cell free medium from a co-culture was able to induce EMT in HNSCC cells. Co-culture treated HNSCC cells revealed increased viability and were less sensitive to CDDP treatment. TGF- $\beta 1$ also induced a mesenchymal phenotype, but did not alter resistance to CDDP in HNSCC cells.

\section{INTRODUCTION}

Most studies on chemotherapy resistance of tumor cells focus on genetic or phenotypic alterations of the cancer cell itself. However, there is growing evidence that the stroma of solid tumors interacts with cancer cells. Tumor-stroma interaction is considered a significant determinant of disease progression and metastasis $[1$, 2]. Stromal fibroblasts induce epithelial to mesenchymal transition (EMT) in head and neck squamous cell carcinoma (HNSCC) tumor cells [3]. EMT is a reversible cellular process mainly induced by paracrine secretion of small molecules by tumor-associated fibroblasts [4]. Among these small molecules, transforming growth factor- $\beta 1$ (TGF- $\beta 1$ ) is thought to be one of the most relevant mediators $[5,6]$. TGF- $\beta 1$ interacts with TGF- $\beta 1$ two type I and two type II transmembrane kinase receptors. These receptors activate Smad 2 and 3 signaling pathways, which form a complex with Smad 4, leading to the expression of EMT-activating transcriptional factors such as Snail/Slug [7]. Two major hallmarks of EMT in epithelial tumor cells are increased expression of the intermediate filament vimentin and decreased expression of E-cadherin [3]. We recently reported that EMT in HNSCC-cell lines results in enhanced cell proliferation [8]. In this study, we analyze if EMT increases CDDP (Cisplatin) resistance in two HNSCC cell lines.

SCC-25 cells were orignially isolated from the primary tumor of a patient with tongue carcinoma [9]. SCC-25 cells form tumors in SCID mice but not in athymic nude mice suggesting less aggressive behavior. Moreover, SCC-25 induced tumors do not develop regional or distant metastasis in mouse models [10]. In contrast, Detroit 562 cells grow tumors and develop regional and lung metastases when injected in nude mice [11]. Detroit 562 was isolated from the malignant pleural 
effusion of a patient with pharyngeal carcinoma $[12,13]$.

Previously, we had induced EMT by co-cultivation of SCC-25 or Detroit 562 cells and fibroblasts [1]. The resulting co-culture conditioned medium containing EMT-promoting factors was used in this study to induce EMT in pure SCC- 25 or Detroit 562 cells. In a second experimental arm, tumor cells were treated with TGF- $\beta 1$. In a third experimental arm tumor cells were treated with co-culture conditioned medium and a neutralizing dose of anti-TGF- $\beta$ antibody. SCC- 25 and Detroit 562 cells treated with standard cell culture medium served as control in a fourth experimental arm. Changes of vimentin and E-cadherin gene expression and protein synthesis, which were evaluated by quantitative real-time polymerase chain reaction (PCR) and by western blotting were used to confirm EMT. Cell viability was determined with MTT assays and colony-forming ability was investigated using clonogenic assays [14]. Response to CDDP was assessed by cell viability and Clonogenic assays.

\section{RESULTS}

\section{Co-culture conditioned medium and TGF- $\beta 1$ induced EMT in SCC-25 cells}

SCC-25 cells were treated with standard medium (control), co-culture conditioned medium or $1 \mathrm{ng} /$ $\mathrm{ml}$ TGF- $\beta 1$ for 3 days. EMT-related gene expression was subsequently measured using real-time PCR and compared with $\beta$-actin expression (Figure 1). Relative gene expression of the mesenchymal marker vimentin was higher in SCC-25 cells treated with coculture conditioned medium $\left(56.6 \pm 22.4 \times 10^{-3}\right)$ than in control cells $\left(27.1 \pm 10.3 \times 10^{-3} ; p<0.001\right)$. In contrast, E-cadherin gene expression was down regulated following treatment with co-culture conditioned medium $\left(1.9 \pm 1.1 \times 10^{-3}\right)$ compared to controls $\left(2.7 \pm 0.9 \times 10^{-3}\right.$; $p<0.02)$. EMT-like gene expression changes were also observed in SCC-25 cells treated with $1 \mathrm{ng} / \mathrm{ml}$ TGF- $\beta 1$. TGF- $\beta 1$ treated cells revealed significantly higher vimentin gene expression $\left(488.1 \pm 48 \times 10^{3}\right)$ than control cells $\left(74.4 \pm 10.1 \times 10^{-3} ; p<0.001\right)$ and lower E-cadherin gene expression levels $\left(0.8 \pm 0.3 \times 10^{-3}\right)$ compared to controls $\left(1.6 \pm 0.9 \times 10^{-3} ; p<0.01\right)$. At protein level both, co-culture conditioned medium and $1 \mathrm{ng} / \mathrm{ml}$ TGF- $\beta 1$, increased a $46 \mathrm{kD}$ vimentin band. E-cadherin showed a marginal decrease after treatment with co-culture conditioned medium and $1 \mathrm{ng} / \mathrm{ml}$ TGF- $\beta 1$ in SCC- 25 cells. Moreover, cell viability of SCC-25 cells treated with co-culture conditioned medium was higher $(1.25 \pm 0.11)$ than in untreated controls $(1.09 \pm 0.23 ; p<0.01)$. In contrast, treatment with TGF- $\beta 1$ decreased cell viability $(0.69 \pm 0.007 ; p<0.001)$ compared to controls treated with albumin-containing medium (Figure $3 \mathrm{~A}$ ).
A neutralizing assay with anti-TGF- $\beta$ antibody did not reduce the influence of co-culture conditioned medium on cell viability $(1.45 \pm 0.03 ; p>0.1)$. The number of colonies in clonogenic assays did not differ between standard-medium (3116 \pm 654$)$ and co-culture conditioned medium $(1805 \pm 131 ; p>0.5)$. Furthermore treatment with TGF- $\beta 1(2547 \pm 80)$ or co-culture conditioned medium and anti-TGF- $\beta(1496 \pm 119)$ antibody had no influence on clonogenity of SCC-25 cells $(p>0.1)$ (Table 1$)$.

\section{Conditioned medium did not induce an EMT like phenotype in detroit 562 cells}

Treatment with co-culture conditioned medium did not induce significant phenotypic changes in Detroit 562 cells. Vimentin expression $\left(0.59 \pm 0.04 \times 10^{-3}\right.$ vs. $\left.0.58 \pm 0.2 \times 10^{-3}, p>0.1\right)$ and E-cadherin expression $\left(3.6 \pm 2.6 \times 10^{-3}\right.$ vs. $\left.4.6 \pm 0.2 \times 10^{-3}, p>0.1\right)$ did not show significant changes after treatment with co-culture conditioned medium. Treatment with TGF- $\beta 1$ induced EMT-like phenotypic changes in Detroit 562 cells. TGF- $\beta 1$ increased vimentin expression about ten fold $\left(5.6 \pm 1.4 \times 10^{-3}\right.$ vs. $\left.0.58 \pm 0.2 \times 10^{-3}, p<0.0001\right)$, but failed to reduce E-cadherin expression $\left(17.5 \pm 1 \times 10^{-3}, p>0.1\right)$. At protein level, both, conditioned medium and $1 \mathrm{ng} / \mathrm{ml}$ TGF- $\beta 1$ did not induce changes in vimentin expression $(46 \mathrm{kD}$ band) (Figure 2). E-cadherin showed a marginal decrease after treatment with co-culture conditioned medium and $1 \mathrm{ng} / \mathrm{ml}$ TGF- $\beta 1$. Viability increased after treatment with co-culture conditioned medium (2.1 \pm 0.04$)$ compared to controls $(1.9 \pm 0.02, p=0.001)$, whereas TGF- $\beta 1$ had no influence on cell viability $(1.9 \pm 0.005, p>0.5)$. A neutralizing assay with anti-TGF- $\beta$ antibody did not reduce the effect of co-culture conditioned medium on cell viability $(2.2 \pm 0.01, p>0.05)$. Treatment with co-culture conditioned medium, TGF- $\beta 1$ and co-culture conditioned medium/anti-TGF- $\beta$ antibody had no effect on clonogenity in Detroit 562 cells (standard medium 948 \pm 153 , CM: $983 \pm 38$, TGF- $\beta 1876 \pm 160$; antiTGF- $\beta$ : $1000 \pm 18 ; p>0.1)($ Table 1$)$.

\section{Treatment with co-culture conditioned medium increased CDDP resistance of SCC-25 cells}

Cell cultures were exposed to CDDP ranging from $0 \mu \mathrm{M}$ to $50 \mu \mathrm{M}$ and cell viability was assessed with MTT assays. Half-maximal inhibitory CDDP concentration was calculated using 4-parameter nonlinear logistic regression. The $\mathrm{IC}_{50}$ for native SCC- 25 cells was $6.24 \mu \mathrm{M}(95 \% \mathrm{CI}$ $5.43 \mu \mathrm{M}$ to $7.06 \mu \mathrm{M})$. Treatment with conditioned medium significantly increased CDDP-chemoresistance (Figure $3 \mathrm{~A})$. It more than doubled the $\mathrm{IC}_{50}$ of SCC- 25 cells to $13.05 \mu \mathrm{M}(95 \%$ CI $10.35 \mu \mathrm{M}$ to $15.76 \mu \mathrm{M} ; p<0.005)$. In addition to viability assays, clonogenic assays following exposure to $5 \mu \mathrm{M}$ CDDP were performed in 


\section{Vimentin in SCC-25}

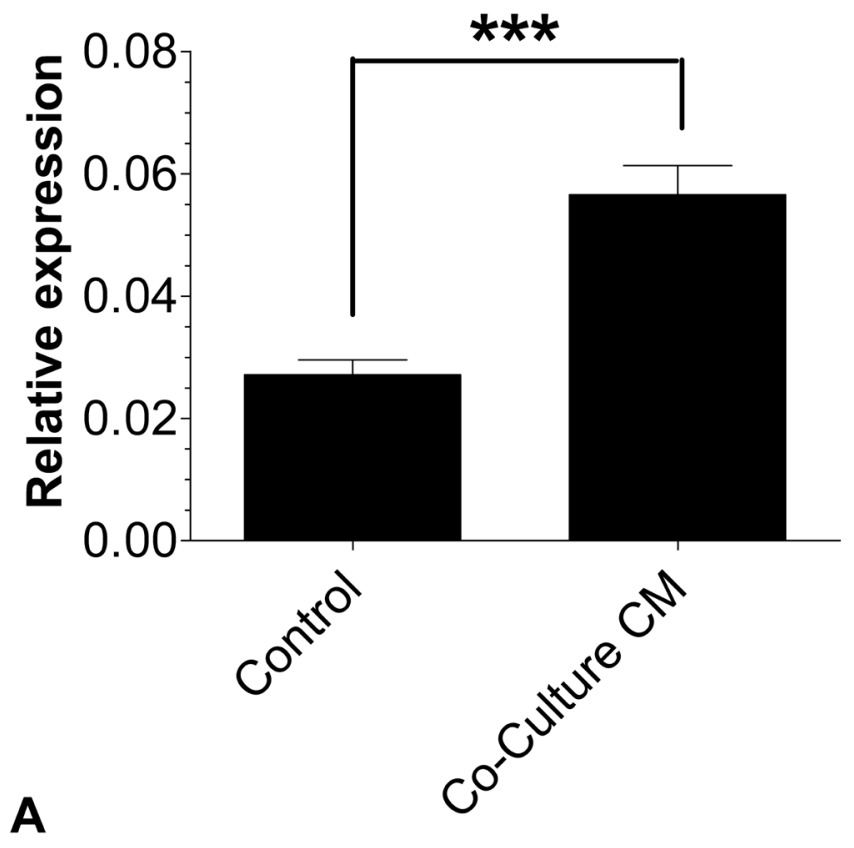

\section{Vimentin in SCC-25}

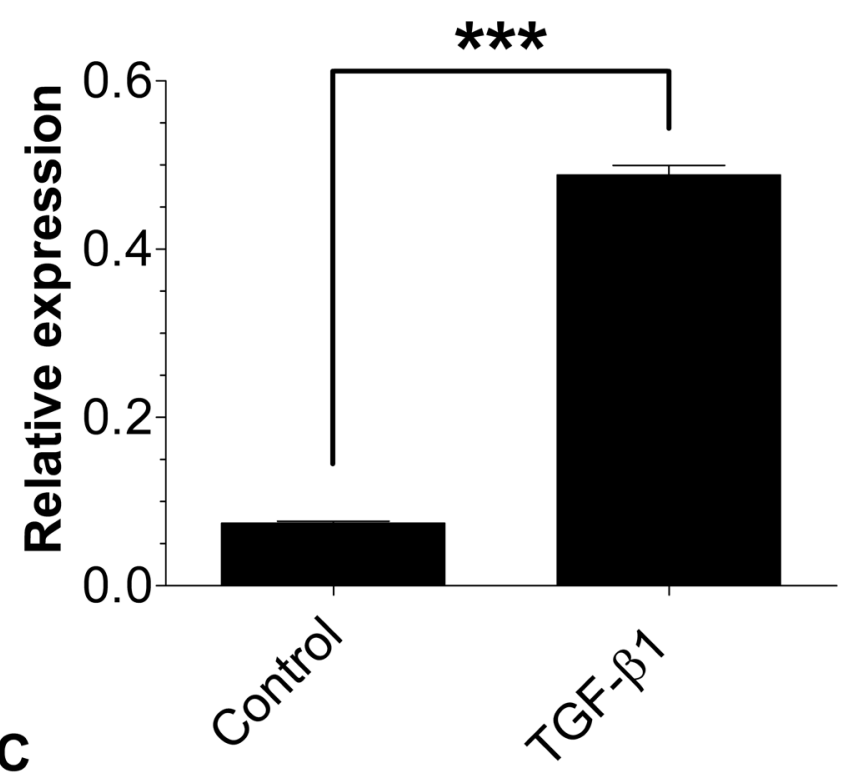

\section{E-cadherin in SCC-25}

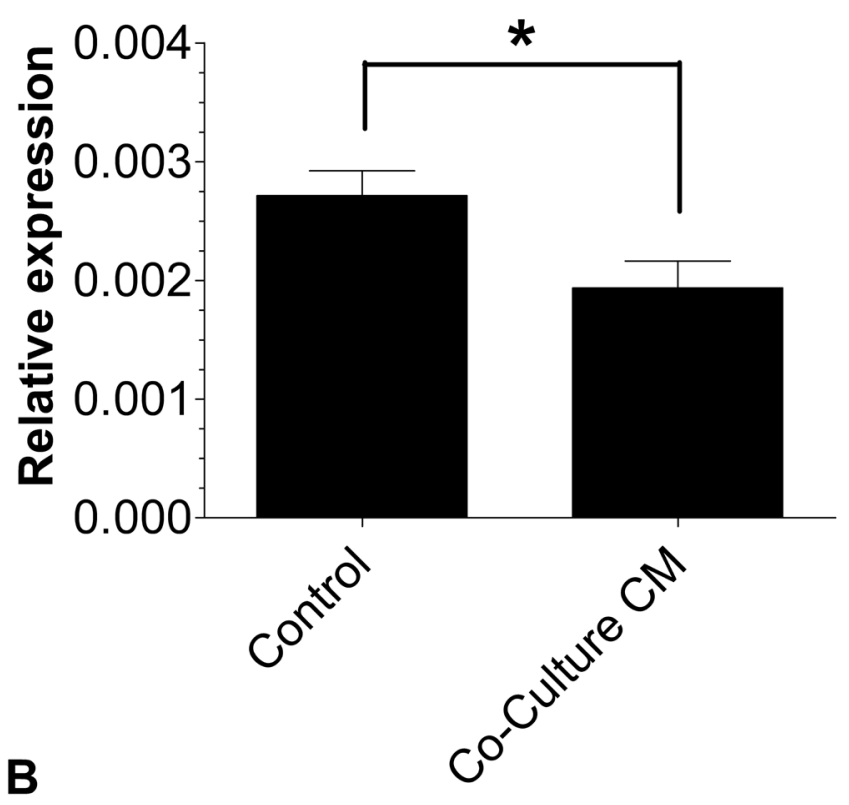

\section{E-cadherin in SCC-25}

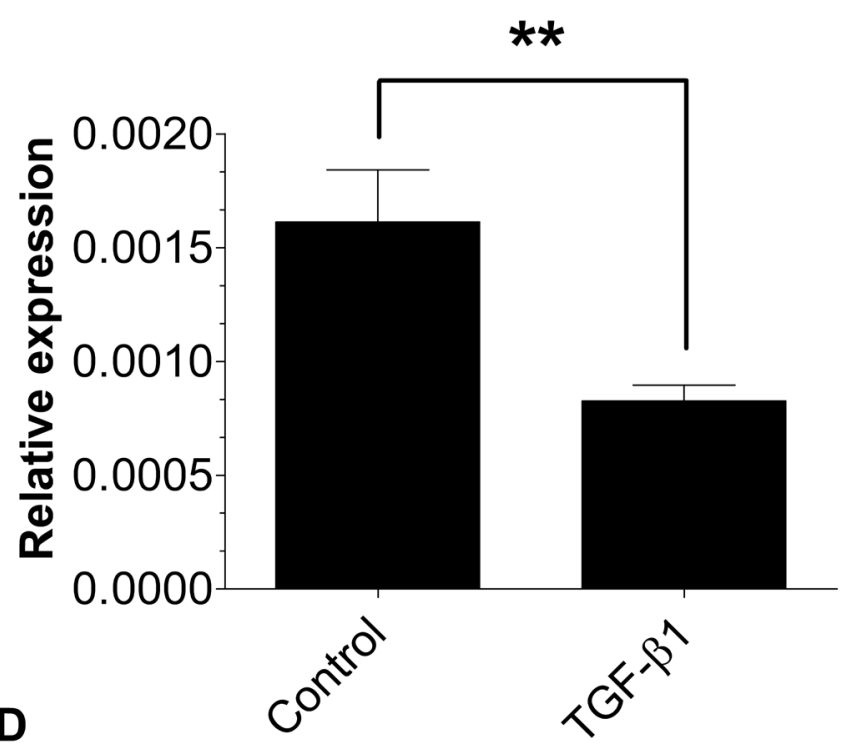

Figure 1: EMT-related gene expression in SCC-25 using real time- PCR: The mRNA expressions of the EMT markers vimentin and E-cadherin in SCC-25 cells treated with co-culture conditioned medium (A, B) or 0.9 ng/ml TGF- $\beta 1$ (C, D) were quantified relative to SCC-25 control cells. Co-culture conditioned medium treated SCC-25 cells show a significant increase of vimentin A. mRNA expression, while E-cadherin B. mRNA expression was significantly decreased. The treatment with $0.9 \mathrm{ng} / \mathrm{ml}$ TGF- $\beta 1$ led to the same effect to an even greater extent with a highly significant upregulation of vimentin $\mathbf{C}$. and downregulation of E-cadherin D. in SCC-25 cells. Experiments were performed in three replicates with three runs each. ${ }^{*} p<0.05,{ }^{* *} p<0.01,{ }^{* * *} p<0.001$. 


\section{SCC-25 Detroit $562 \quad$ Fibs}

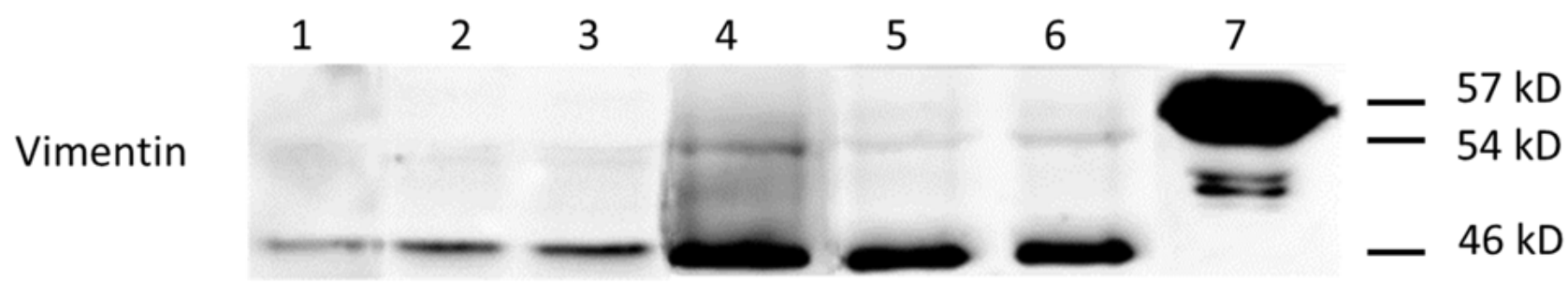

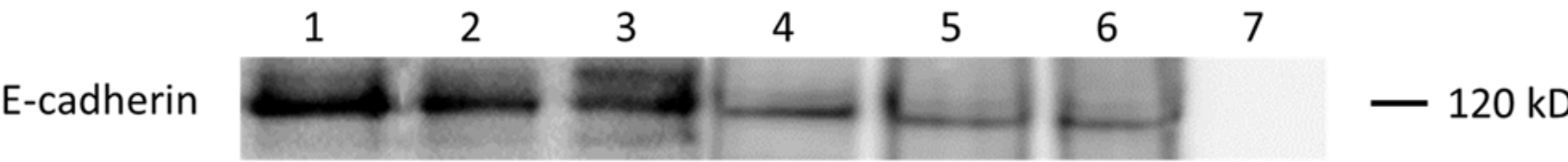
1
2
3
4
5
6
7

GAPDH

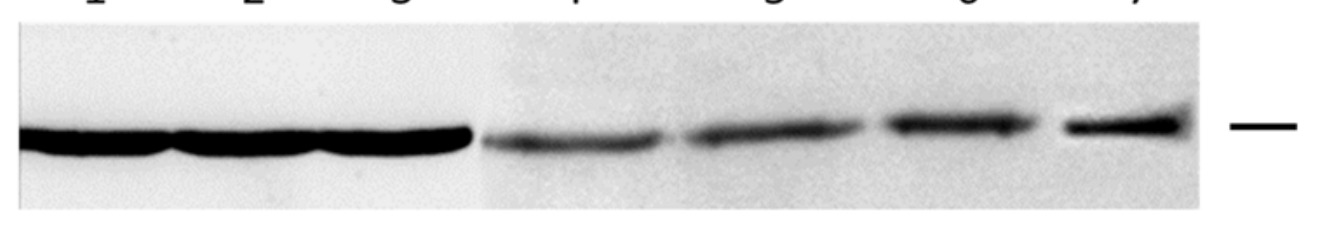

Figure 2: EMT-related protein synthesis in SCC-25 and Detroit 562 cells. Western blots of (supernatants/cell homgenisates), representative sample of three replicates. Lane 1: SCC-25 cells in albumin-containing medium (control), Lane 2: SCC-25 treated with coculture conditioned medium, Lane 3: SCC-25 treated with $1 \mathrm{ng} / \mathrm{ml}$ TGF- $\beta 1$, Lane 4: Detroit 562 in albumin-containing medium (control), Lane 5: Detroit 562 treated with co-culture conditioned medium, Lane 6: Detroit 562 treated with $1 \mathrm{ng} / \mathrm{ml} \mathrm{TGF-} \beta 1$, Lane 7: human gingival fibroblasts. Vimentin was detected in 57,54 and $46 \mathrm{kD}$ bands. In SCC-25 cells, co-culture conditioned medium and $1 \mathrm{ng} / \mathrm{ml} \mathrm{TGF} \beta 1$ increased the 54 and $46 \mathrm{KD}$ bands. There was a high constitutive expression of $46 \mathrm{kD}$ vimentin in Detroit 562 cells without any treatment. The treatment with co-culture conditioned medium did not increase both vimentin bands. The positive control HGF fibroblasts showed a strong band at $57 \mathrm{kD}$. E-cadherin was detected at $120 \mathrm{kD}$. SCC-25 cells at control conditions showed a strong $120 \mathrm{kD}$ band, which was reduced after treatment with co-culture conditioned medium or with $1 \mathrm{ng} / \mathrm{ml}$ TGF- $\beta 1$. Detroit 562 cells showed a light band at $120 \mathrm{kD}$, which was marginally reduced after treatment with co-culture conditioned medium or with $1 \mathrm{ng} / \mathrm{ml} \mathrm{TGF-} \beta 1$ The control HG-fibroblasts did not not express protein at $120 \mathrm{kD}$ with the vimentin antibody. Loading control was done using anti-GAPDH antibody.

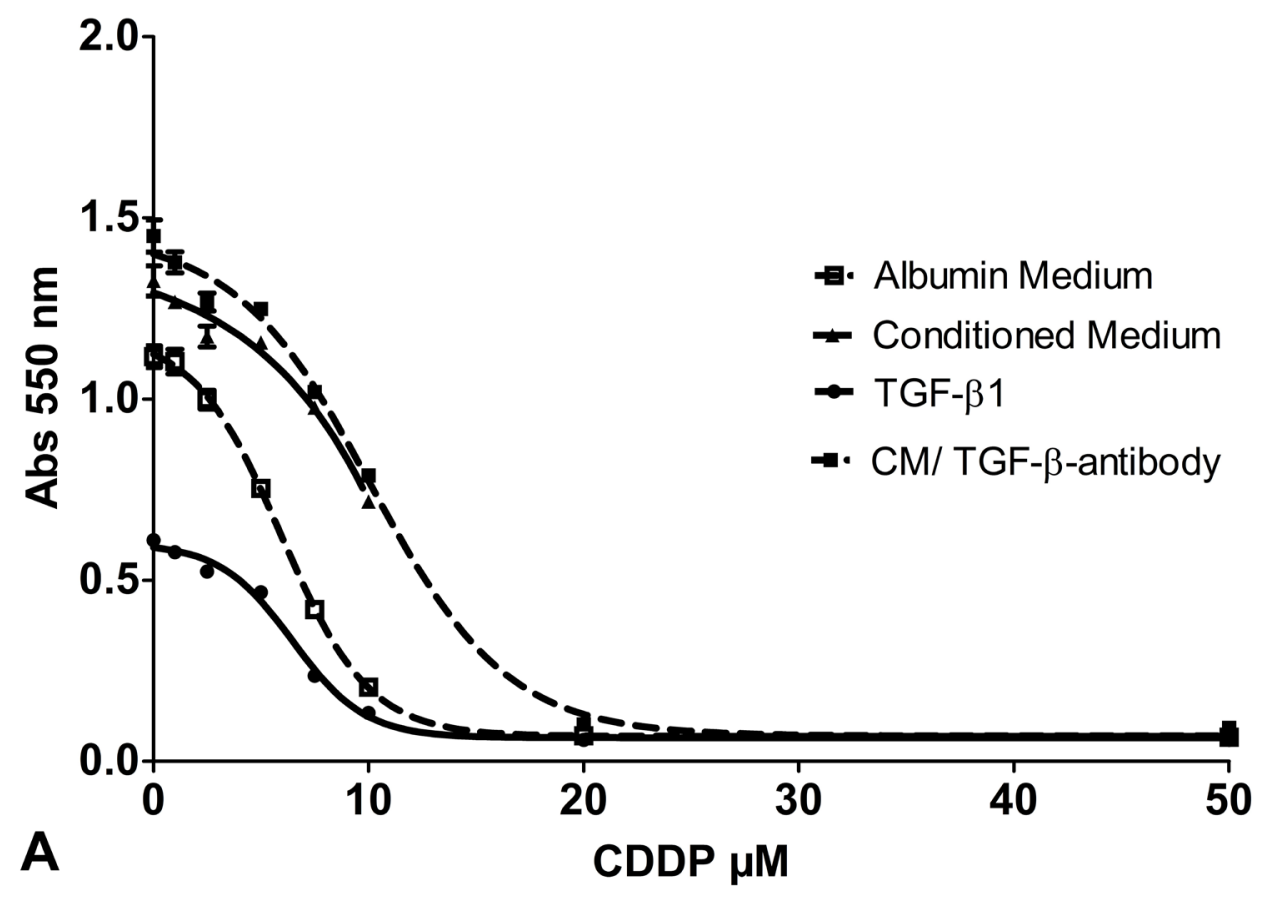




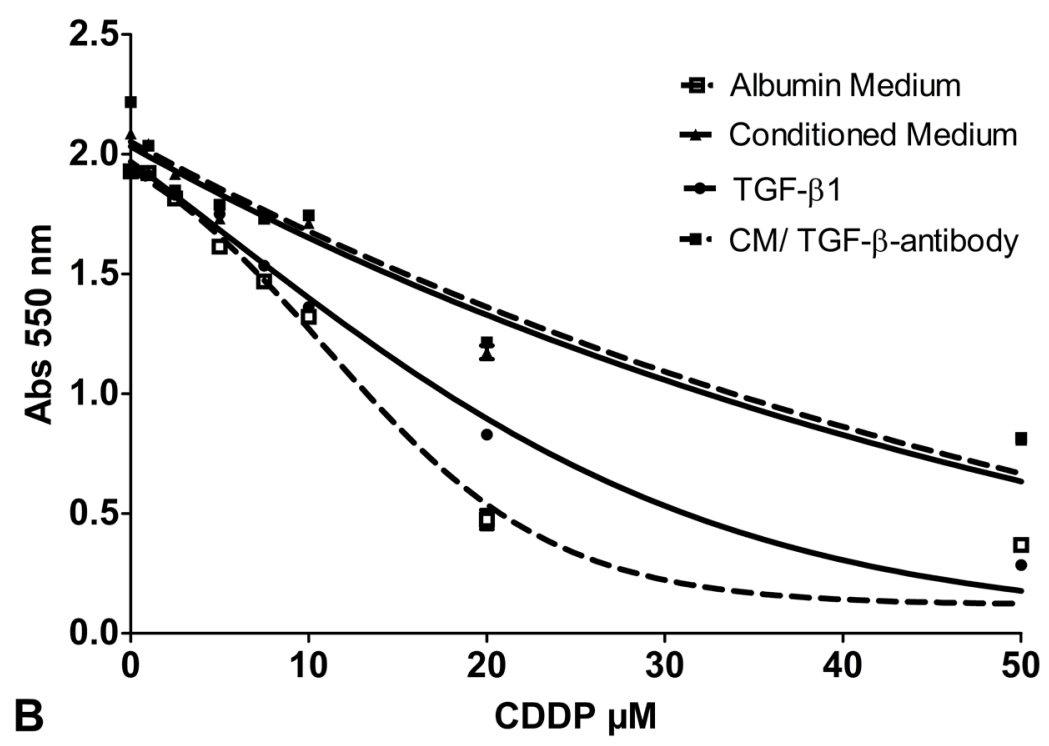

Figure 3: Cell viability assay: Cell viability of SCC-25 cells A. or Detroit 562 cells fat as well B. exposed to increasing doses of $\operatorname{CDDP}(0-50 \mu \mathrm{M})$ following treatment with albumin containing medium (control; dotted line with white squares), co-culture conditioned medium (solid line with triangles), medium supplemented with TGF- $\beta 10.9 \mathrm{ng} / \mathrm{ml}$ (dotted line with spheres) and co-culture conditioned medium plus anti TGF- $\beta$ antibody $(1.5 \mu \mathrm{g} / \mathrm{ml})$ (solid line with black squares). Four parameter nonlinear logistic regression model, whiskers indicate standard error of the mean (SEM).

Table 1: Co-culture conditioned Medium and TGF-ß1 induced EMT in SCC-25 cells and did not influence the phenotype of Detroit 562 cells

\begin{tabular}{|l|l|l|l|}
\hline Cell type & Test & conditioned Medium & TGF-ß31 \\
\hline SCC-25 & Vimentin PCR (RNA) & upregulation*** & upregulation*** \\
\hline & E-cadherin PCR (RNA) & downregulation* & downregulation** \\
\hline & vimentin Western Blot (protein) & upregulation (46kD) & upregulation (46kD) \\
\hline & $\begin{array}{l}\text { E-cadherin Western blot } \\
\text { (protein) }\end{array}$ & downregulation & downregulation \\
\hline & viability & increase** & decrease*** \\
\hline & clonogenity & no change & no change \\
\hline Detroit 562 & Vimentin PCR (RNA) & no change & upregulation*** \\
\hline & E-cadherin PCR (RNA) & no change & no change \\
\hline & Vimentin Western blot (protein) & no change & no change \\
\hline & $\begin{array}{l}\text { E-cadherin Western blot } \\
\text { (protein) }\end{array}$ & downregulation & downregulation \\
\hline & viability & increase*** & no change \\
\hline & clonogenity & no change & no change \\
\hline
\end{tabular}

$* p<0.05, * * p<0.01, * * * p<0.001$

Table 2: Treatment with co-culture conditioned medium resulted in increased CDDP resistance (measured with cell viability and clonogenity) in both cell lines

\begin{tabular}{|l|l|l|l|l|}
\hline Cell type & Parameter & Cond. Medium & TGF-ß1 & Cond.Medium + anti TGF-ß \\
\hline SCC-25 & $\mathrm{IC}_{50}$ & increased *** & no change & increased*** \\
\hline & $\begin{array}{l}\text { Clonogenity after } 5 \mu \mathrm{M} \\
\text { CDDP }\end{array}$ & increased $* *$ & no change & increased*** \\
\hline Detroit 562 & $\mathrm{IC}_{50}$ in $\mu \mathrm{M}$ & increased** & no change & increased** \\
\hline & $\begin{array}{l}\text { Clonogenity after } \\
10 \mu \mathrm{M} \text { CDDP }\end{array}$ & increased* & no change & increased*** \\
\hline
\end{tabular}

TGF- $ß 1$ treatment did not influence CDDP resistance. A neutralizing assay performed with anti-TGF- $\beta$ antibody supported this concept because it did not alter the CDDP resistance induced by co-culture conditioned medium. $* p<0.05, * * p<0.01, * * * p<0.001$ 
control and co-culture conditioned medium treated cells. In control cells, $5 \mu \mathrm{M}$ CDDP reduced colony number from $3116 \pm 654$ to $82 \pm 8$ (91\% reduction). In co-culture conditioned medium-treated cells, $5 \mu \mathrm{M}$ CDDP reduced colony number from $1805 \pm 131$ to $1106 \pm 381 \quad(39 \%$ reduction). This means CDDP induced significant less $(p=0.013)$ reduction of colony numbers in co-culture cells than in standard-culture cells, suggesting an increased CDDP-chemoresistance following exposure to conditioned medium (Figure 4A-4C). In addition, SCC-25 cells were incubated with $1 \mathrm{ng} / \mathrm{ml}$ TGF- $\beta 1$ and CDDP to evaluate the specific effect of TGF- $\beta 1$ on CDDP resistance (Figure $3 \mathrm{~A}$ ). The $\mathrm{IC}_{50}$ following TGF- $\beta 1$ exposure $(6.6 \mu \mathrm{M} ; 95 \%$ CI $5.47 \mu \mathrm{M}$ to $7.73 \mu \mathrm{M})$ did not differ from the $\mathrm{IC}_{50}$ following standard medium $(p>0.2)$. TGF- $\beta 1$ treatment did not alter clonogenity after treatment with $5 \mu \mathrm{M} \operatorname{CDDP}(95 \pm 11, p>0.1$, $89 \%$ reduction) compared to controls (Figure $4 \mathrm{C}$ ).

To support the observation that TGF- $\beta 1$ is not involved in co-culture conditioned medium induced chemoresistance, a neutralizing dose of anti-TGF- $\beta$ (1.5 $\mu \mathrm{g} / \mathrm{ml}$ ) was added to the co-culture medium before viability and clonogenity assays were performed. Despite that, the chemoresistance mediating effect of co-culture conditioned medium was preserved. Also with anti-TGF- $\beta$, the $\mathrm{IC}_{50}$ of CDDP following administration of co-culture conditioned medium remained significantly higher than in control experiments $(10.4 \mu \mathrm{M}, 95 \%$ CI 9.2 to $11.5 \mu \mathrm{M}(p<0.05)$ (Figure 3A). The effect of co-culture conditioned medium on clonogenity after treatment with $5 \mu \mathrm{M}$ was not altered by anti-TGF- $\beta$ antibody treatment $(1281 \pm 20,13 \%$ reduction, $p>0.5$ ) (Figure $4 \mathrm{C}$ ).

\section{Treatment with co-culture conditioned medium increased CDDP resistance of detroit 562 cells}

The same experiments were repeated in Detroit 562 cells. The $\mathrm{IC}_{50}$ of CDDP for native Detroit 562 cells was $13.1 \mu \mathrm{M}(95 \%$ CI 9.8 to $16.5 \mu \mathrm{M})$. Treatment with coculture conditioned medium more than doubled the $\mathrm{IC}_{50}$ to $26.8 \mu \mathrm{M}(95 \%$ CI 12.7 to $41.0 \mu \mathrm{M})(\mathrm{p}<0.01)$ (Figure 3B). In control cells $10 \mu \mathrm{M}$ CDDP reduced the colony number to $252 \pm 69$ ( $73 \%$ reduction). In co-culture conditioned medium treated cells $10 \mu \mathrm{M}$ CDDP reduced the colony number to $490 \pm 1(50 \%$ reduction) $(p<0.05)$ (Figure $4 \mathrm{D})$. Treatment with $1 \mathrm{ng} / \mathrm{ml}$ TGF- $\beta 1$ had no influence on the $\mathrm{IC}_{50}$ of CDDP in Detroit 562 cells, the $\mathrm{IC}_{50}$ remained stable with $16.9 \mu \mathrm{M}(95 \%$ CI 14.9 to $19 \mu \mathrm{M}, p>0.05)$ (Figure $3 \mathrm{~B})$. TGF- $\beta 1$ treatment did not alter clonogenity after treatment with $10 \mu \mathrm{M}$ CDDP $(193 \pm 6, p>0.3)$ compared to controls cells (Figure 4D). Accordingly, treatment with co-culture conditioned medium containing a neutralizing dose of anti-TGF- $\beta 1$-antibody $(1.5 \mu \mathrm{g} / \mathrm{ml})$ did not change the $\mathrm{IC}_{50}$ of CDDP in Detroit 562 cells compared to co-culture conditioned medium treated Detroit 562 cells
( IC $_{50} 27.5 \mu \mathrm{M}, 95 \%$ CI 18.5 to $36.3 \mu \mathrm{M}, p>0.05$ ) (Figure $3 \mathrm{~B})$. Treatment with anti-TGF- $\beta$-antibody/co-culture conditioned medium and $10 \mu \mathrm{M}$ CDDP did not alter the effect of conditioned medium on clonogenity of Detroit 562 cells $(504 \pm 6, p>0.05)$ (Figure 4D) (Table 2).

\section{DISCUSSION}

EMT is a reversible cellular process caused by the interaction of epithelial tumor cells and tumor-associated fibroblasts. During EMT, epithelial tumor cells acquire characteristics of a mesenchymal phenotype. It is thought to be a relevant mechanism of cancer progression $[5,6]$. In this study, we were interested in the effect of EMT on CDDP resistance of HNSCC tumor cells in vitro. Co-cultures of epithelial and mesenchymal cells are frequently used to model EMT in vitro. Here we used a direct fibroblast-tumor cell co-culture conditioned medium to induce EMT in the two human papilloma virus-negative HNSCC cell lines SCC-25 and Detroit 562.

\section{Co-culture conditioned medium induced EMT and increased cell viability}

Co-culture conditioned medium upregulated vimentin expression and downregulated E-cadherin expression in SCC-25 cells. As expected for an epithelial cell line, baseline vimentin expression was low and baseline E-cadherin expression was high. Similar phenotypic changes were induced by treatment with $1 \mathrm{ng} / \mathrm{ml}$ TGF- $\beta 1$. This TGF- $\beta 1$ concentration has previously been measured in co-culture conditioned medium using enzyme-linked immunoassays (data not shown). TGF- $\beta 1$ is considered a major factor for phenotypic changes in EMT [15].

Especially $46 \mathrm{kD}$ vimentin protein levels increased in SCC- 25 cells after treatment with co-culture conditioned medium and TGF- $\beta 1.46 \mathrm{kD}$ vimentin had been previously identified in epithelial cells under stress conditions [16]. On the protein level, co-culture conditioned medium and TGF- $\beta 1$ slightly reduced the E-cadherin expression. The fact that EMT can be induced by cell free medium supports the concept that EMT mainly depends on paracrine signaling $[8,17,18]$. Beyond upregulation of mesenchymal and downregulation of epithelial markers, the co-culture conditioned medium increased cell viability in SCC 25 cells $(p<0.01)$. EMT-associated increase of cell viability is in line with several recent reports $[4,19]$.

This effect was not mediated by TGF- $\beta 1$, since TGF- $\beta 1$ reduced cell viability in SCC-25 cells $(p<0.001)$. It was demonstrated that Smad 4 is active in SCC-25 cells, which might enable a tumor suppressive effect of TGF- $\beta 1$ [20]. Apparently, other factors than TGF- $\beta 1$ are responsible for increased viability in SCC- 25 cells exposed to co-culture conditioned medium and these 
factors are even able to override TGF- $\beta 1$ induced viability reduction in SCC-25 cells. Moreover, the discrepancy of co-culture conditioned medium and TGF- $\beta 1$ induced effects on EMT and cell viability implies that observed changes in cell viability are not caused by the acquisition of a mesenchymal phenotype (EMT), but rather an EMT
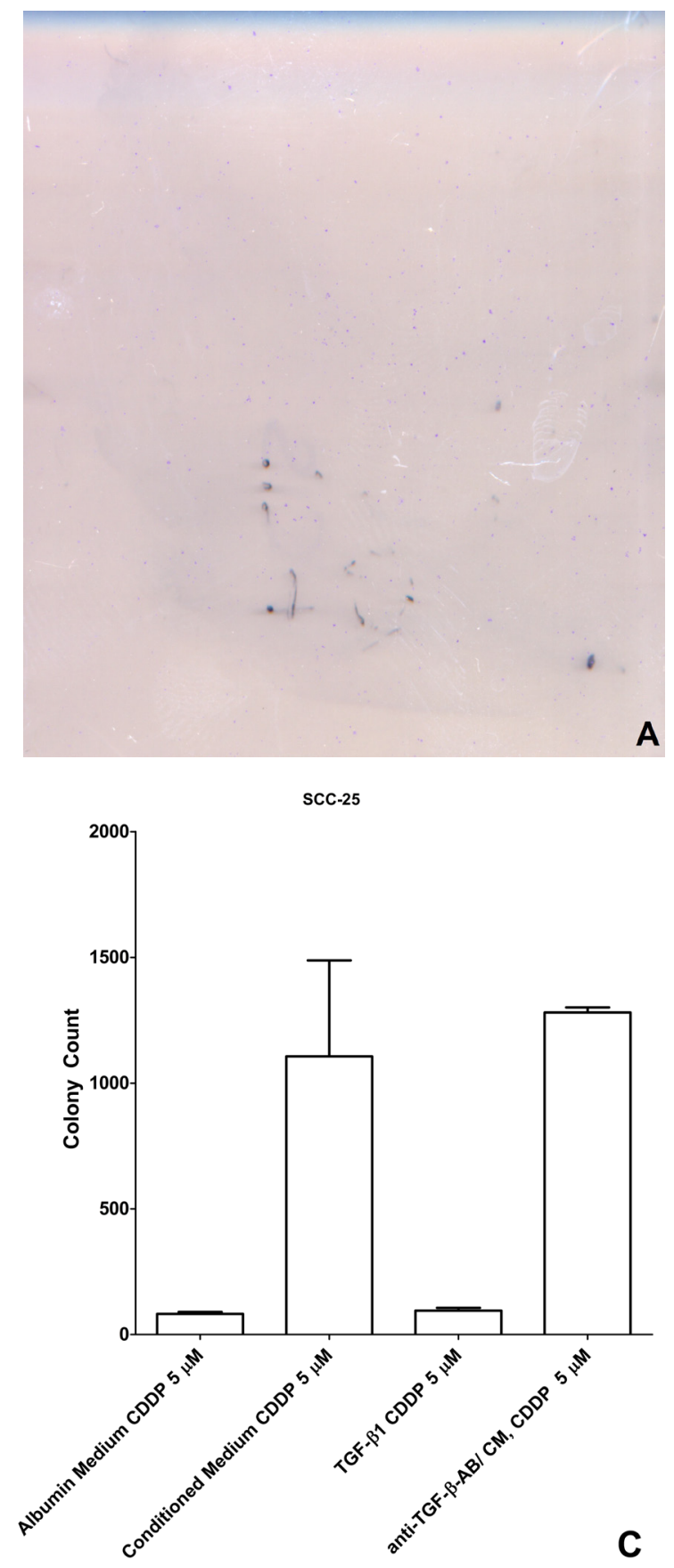

associated effect of epithelial-mesenchymal crosstalk in the tumor microenvironment.

Despite lack of phenotypic changes, coculture conditioned medium increased cell viability of Detroit 562 cells $(p=0.001)$, supporting the concept that EMT-induction and changes in cell
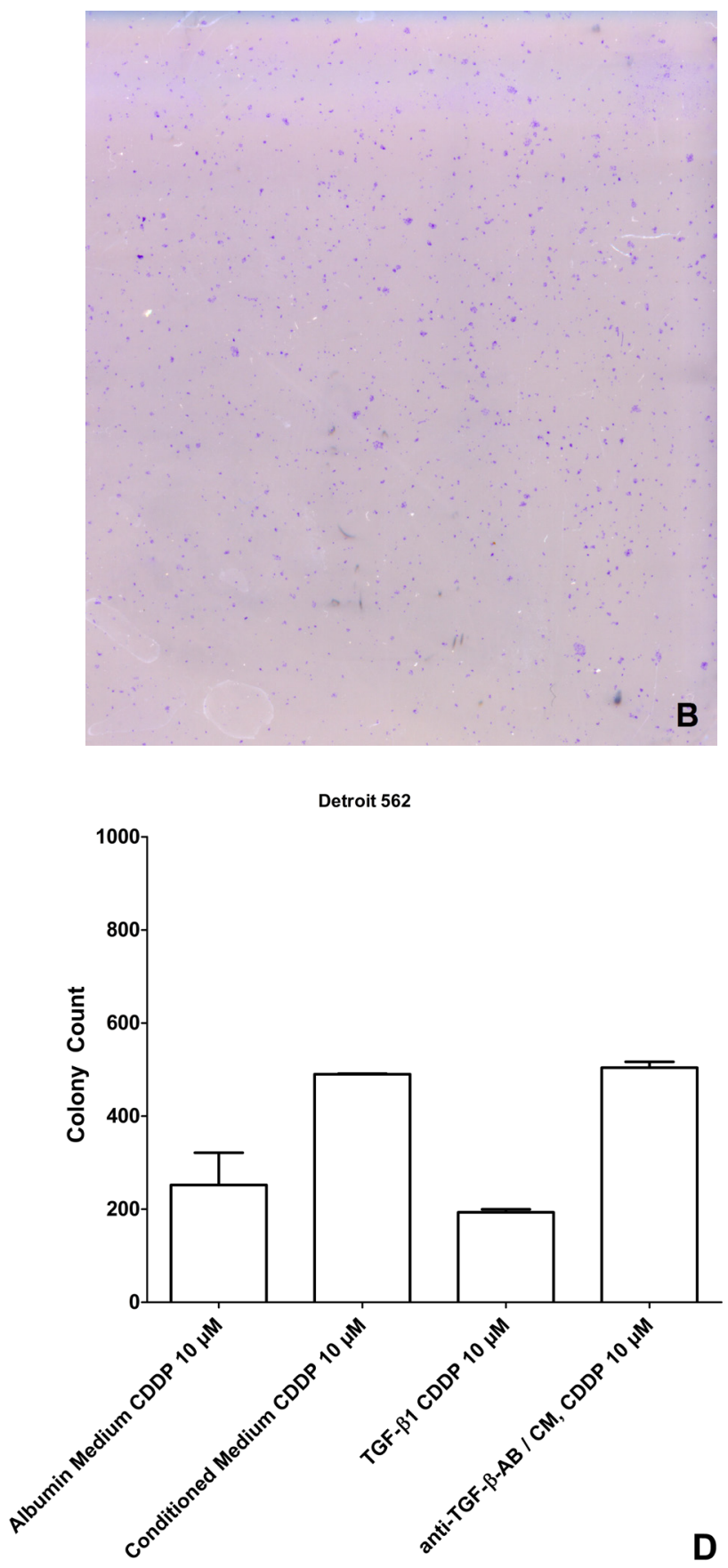

Figure 4: Clonogenic assay after treatment with albumin medium/ conditioned medium and CDDP $0 \mu M, 5 \mu M, 10 \mu M:$ A. Picture of the clonogenic assay of the control SCC- 25 cells after treatment with $5 \mu \mathrm{M}$ CDDP. B. Picture of the clonogenic assay of the SCC-25 cells cultured in co-culture conditioned medium after treatment with $5 \mu$ M CDDP. C. Number of colonies as a function of treatment. This demonstrates the significant increased colony forming ability of the SCC- 25 cells after treatment with co-culture conditioned medium or co-culture conditioned medium/ anti-TGF- $\beta$-antibody $(1.5 \mu \mathrm{g} / \mathrm{ml})$ and CDDP $5 \mu \mathrm{M}$ compared to controls or cells treated with TGF- $\beta 11 \mathrm{ng} / \mathrm{ml}$. D. Number of colonies as a function of treatment. This demonstrates the significant increased colony forming ability of the Detroit 562 cells after treatment with co-culture conditioned medium or co-culture conditioned medium/ anti-TGF- $\beta$-antibody (1.5 $\mu \mathrm{g} /$ $\mathrm{ml}$ ) and CDDP $10 \mu \mathrm{M}$ compared to the controls or cells treated with TGF- $\beta 11 \mathrm{ng} / \mathrm{ml}$. 
viability may be caused by different factors. Consistent with the observations in SCC-25 cells, TGF- $\beta 1$ had no influence on cell viability and clonogenity in Detroit 562 cells.

\section{Co-culture conditioned medium induced CDDP chemoresistance}

The main goal of this study was to determine if EMT is associated with increased CDDP chemoresistance. Medium from an epithelialmesenchymal co-culture more than doubled the $\mathrm{IC}_{50}$ of CDDP in MTT assays in both cell lines $(p<0.001)$ (Figure 2). These results are consistent with the outcome of clonogenic assays. The anti-clonogenic effect of CDDP was significantly reduced after pretreatment with co-culture conditioned medium $(p<0.05)$ (Table 2). Hazlehurst et al. observed in 2001 that tumor microenvironment is involved in cell cycle arrest and drug resistance. This so called microenvironment related drug resistance is mediated through survival pathways activated as a result of cell-cell-adhesion (cell-adhesion mediated drug resistance) and extracellular matrix derived adhesive signals, which reduce the cytotoxic effect of CDDP [21]. Niessner et al. reported that the release of paracrine signaling factors produced by carcinoma-associated fibroblasts stimulate survival pathways such as the Aktpathway and reduce cytotoxic effects of chemotherapies [22]. We treated HNSCC cell lines with a cell-free conditioned medium, suggesting the latter being responsible for the increase in CDDP resistance in our experimental setting. Similar results have been demonstrated in lung cancer cells. In these cells treatment with fibroblast-conditioned medium increased Paclitaxel resistance by restraining Paclitaxel induced apoptosis by activation of both extracellular signal-regulated kinases (Erk) $1 / 2$ and Akt kinase. In this study, treatment with fibroblast-conditioned medium did not alter the CDDP resistance of lung cancer cells in vitro [23].

\section{No effect of TGF- $\beta 1$ on CDDP sensitivity}

TGF- $\beta 1$ did not increase the $\mathrm{IC}_{50}$ of CDDP of HNSCC cells in vitro. The $\mathrm{IC}_{50}$ of control and TGF- $\beta 1$ treated cells was remarkably similar. Consistently, treatment with TGF- $\beta 1$ had no influence on colony forming ability following CDDP-treatment. To support this observation, an additional experiment with co-culture conditioned medium supplemented with a neutralizing anti-TGF- $\beta$ antibody was performed. Anti-TGF- $\beta$ did not antagonize chemoresistance induction by co-culture conditioned medium in both cell lines. This supports the concept that increased CDDP-resistance is not caused, but merely associated with the acquisition of a mesenchymal phenotype. The factors leading to increased CDDP resistance following epithelial-mesenchymal interaction are not yet identified, but it doesn't seem to be TGF- $\beta 1$. Gilbert et al. reported that IL-6 (Interleukin-6) and TIMP (Tissue Inhibitor of metalloproteinase) could be possible tumor stroma-derived factors, which promote the survival of cancer cells [24]. Other fibroblastproduced mediators which might mediate EMT-associated chemoresistance, are HGF (human hepatocyte growth factor), MED12 (mediator complex subunit 12) and PGE2 (Prostaglandine-E2) [15].

\section{MATERIALS AND METHODS}

\section{Cell lines}

Human gingival fibroblasts (HGF) cells were purchased from Cell Line Service, Eppelheim, Germany $[1,25]$. They were cultured in DMEM-low glucose (PAA, Pasching, Austria) supplemented with 10\% foetal bovine serum (FBS) (PAA), 2 mM l-glutamine, 100 units $/ \mathrm{ml}$ penicillin, and $100 \mu \mathrm{g} / \mathrm{ml}$ streptomycin. SCC-25 were purchased from German Collection of Microorganisms (DSMZ, Braunschweig, Germany) and Detroit 562 cells from the Cell Lines Service (Eppelheim, Germany), and were cultured in DMEM/F12 (PAA) supplemented with 10\% FBS (PAA), 2 mM l-glutamine, 100 units $/ \mathrm{ml}$ penicillin, and $100 \mu \mathrm{g} / \mathrm{ml}$ streptomycin [1].

\section{Co-culture conditioned medium}

For the production of co-culture conditioned medium, $4 \times 10^{4} / \mathrm{ml} \mathrm{SCC}-25$ or Detroit 562 cells and $1 \times 10^{4}$ $\mathrm{HGF}$ cells/ml were plated in $250 \mathrm{ml}$ cell culture flasks and cultured for 72 hours in $15 \mathrm{ml}$ foetal bovine serumcontaining medium (1:1 mix of DMEM/F12 (PAA) and DMEM-low glucose (PAA) supplemented with 10\% foetal bovine serum (FBS) (PAA), 2 mM l-glutamine, 100 units $/ \mathrm{ml}$ penicillin, and $100 \mu \mathrm{g} / \mathrm{ml}$ streptomycin). Then the cells were washed twice with Dulbecco's PhosphateBuffered Saline (DPBS) (Biowhittaker ${ }^{\circledR}$, Belgium) and the serum-containing medium was replaced by $15 \mathrm{ml}$ albumin-containing medium (7,5 ml DMEM/F12 (PAA) and 7,5 ml DMEM-low glucose (PAA) supplemented with bovine serum albumin (BSA, PAA) (0.4 g albumin/ 100 $\mathrm{ml}$ medium) replacing the protein content of $10 \% \mathrm{FBS}$, $2 \mathrm{mM}$ l-glutamine, 100 units/ml penicillin, and $100 \mu \mathrm{g} /$ $\mathrm{ml}$ streptomycin). Albumin-containing medium was left 48 hours on the co-culture allowing interacting epithelial cells and fibroblasts to secrete EMT-related factors into the medium. Afterwards, the co-culture conditioned medium was collected and cells were counted. The co-culture conditioned medium was portioned according to cell numbers as described by Hassona et al. [18]. The co-culture conditioned medium was sterile-filtered and 
stored at $-80^{\circ} \mathrm{C}$.

\section{Stimulation of SCC-25/ Detroit 562 cells with co- culture conditioned medium and TGF- $\beta 1$}

To induce EMT in the first experimental arm, SCC-25/ Detroit 562 cells were treated with $7 \mathrm{ml}$ co-culture conditioned medium per $50 \mathrm{ml}$ cell culture flask for 72 hours. The medium was changed daily. To assess the effects of TGF- $\beta 1$ in the second experimental arm, SCC-25/ Detroit 562 cells were cultivated in albumincontaining medium supplemented with TGF- $\beta 11 \mathrm{ng} / \mathrm{ml}$ (R\&D Systems ${ }^{\circledR}$, Minneapolis, US). Exposure conditions were the same as in the first experimental group, i.e., TGF- $\beta 1$ supplemented medium was used over a period of 72 hours and media were changed daily. A TGF- $\beta 1$ neutralizing assay was performed in the third experimental arm. SCC- 25 cells and Detroit 562 were therefore treated with anti- TGF- $\beta$ 1,-2,-3 antibody (R\&D Systems ${ }^{\mathrm{TM}}$, Biomedica, Vienna; Austria) $1.5 \mu \mathrm{g} / \mathrm{ml}$ medium, as neutralizing dose assayed by the provider and $7 \mathrm{ml}$ co-culture conditioned medium per $50 \mathrm{ml}$ cell culture flask for 72 hours. Exposure conditions were the same as in the other experimental groups. In the fourth experimental arm, standard medium was used with identical media changes. At the end of the stimulation period, cells were used for RNA extraction, protein isolation, MTT assays and clonogenic assays, respectively.

\section{RNA extraction, reverse transcription and real- time RT-PCR}

A fraction of SCC-25/ Detroit 562 cells was harvested and RNA was isolated using TRIzol ${ }^{\circledR}$ reagent following the manufacturer's instructions (Ambion ${ }^{\circledR}$, Life technologies ${ }^{\mathrm{TM}}$, Thermo Fisher Scientific Inc., Waltham, MA, USA). RNA concentrations were determined by photometric measurements (BioPhotometer plus 6132, Eppendorf, Germany). Total RNA was reverse transcribed by M-MuLV Reverse Transcriptase (GeneON, Ludwigshafen, Germany) according to the manufacturer's instructions in a MyiQTM cycler (BIO-RAD Laboratories, Inc., US). Real-Time quantitative PCR (qPCR) of copyDNA transcripts was performed in a MyiQTM cycler (BIO-RAD Laboratories Inc., Hercules, CA, US) using iTaqTM Universal SYBR ${ }^{\circledR}$ Green Supermix (BIO-RAD Laboratories, Inc., Hercules, CA, US). $\beta$-Actin primers were purchased from Invitrogen ${ }^{\mathrm{TM}}$ (Darmstadt, Germany), while E-cadherin and vimentin primers were provided by Eurofins MWG Operon, Inc. (Ebersberg, Germany). $\beta$-Actin functioned well as a housekeeping gene and did not show significant changes across the three treatment conditions. Moreover, the size of the Real-Time PCR products was confirmed by agarose gel electrophoresis analysis.

\section{Protein isolation and western blotting}

Following treatments SCC-25 and Detroit 562 cells were washed twice with DPBS and collected with Accutase (PAA), followed by cell counting and harvesting by centrifugation at $290 \mathrm{~g}, 5$ minutes, $4{ }^{\circ} \mathrm{C}$. The resulting cell pellets were resuspended in $100 \mu 1$ RIPA-buffer ( $50 \mathrm{mM}$ Tris $\mathrm{HCl} / \mathrm{pH}: 8.0,2$ mM EDTA, 1 mM EGTA, $1 \%$ Triton $\mathrm{X}-100,0.25 \%$ sodium deoxycholate, $0.1 \%$ sodium dodecylsulfate, $150 \mathrm{mM} \mathrm{NaCl}, 10 \mathrm{mM} \mathrm{NaF}, 1 \mathrm{mM}$ PMSF) / $10^{6}$ cells. The cell suspension was vortexed and incubated 3-times for 15 minutes on ice, homogenized in $22 \mathrm{G}$ needles and centrifuged at $15000 \mathrm{~g}, 15$ minutes, $4{ }^{\circ} \mathrm{C}$. The cleared supernatant was subjected to protein concentration measurement using the Pierce $660 \mathrm{~nm}$ protein assay (Pierce, Rochford, IL, USA) according to the instructions of the manufacturer. $15 \mu \mathrm{g}$ protein from all samples was subsequently processed for western blot analysis published previously [17], using primary antibodies: mouse monoclonal anti-vimentin (clone VI10) $\operatorname{IgM}$ (Exbio, Prague, Czech Republic) at 1:200, or mouse monoclonal anti-E-cadherin (clone 36) IgG2a (BD Transduction Laboratories, BD Austria, Vienna, Austria) at 1: 2500, or anti-GAPDH (clone 6C5) IgG1 (Santa Cruz Biotechnology, Santa Cruz, CA, USA) at 1: 200. For signal detection horseradish peroxidase coupled matched secondary antibodies and chemiluminescent substrate of Thermo Fisher Scientific (Vienna, Austria) were used in conditions suggested by the manufacturer. The chemilumescence signal was imaged by an Azure C500 documentation system (Biomedica, Vienna, Austria).

\section{Treatment of the cells with $\mathrm{CDDP}$ and $\mathrm{IC}_{50}$ determination}

Following stimulation SCC-25/ Detroit 562 cells were treated with increasing doses of $\operatorname{CDDP}(0 \mu \mathrm{M}, 1 \mu \mathrm{M}$, $2.5 \mu \mathrm{M}, 5 \mu \mathrm{M}, 7.5 \mu \mathrm{M}, 10 \mu \mathrm{M}, 20 \mu \mathrm{M}, 50 \mu \mathrm{M}, 100 \mu \mathrm{M})$ for three days. The medium was changed daily. Cell viability was plotted against CDDP-concentration and $\mathrm{IC}_{50}$ was calculated employing a four-parameter nonlinear regression model [26]. For the clonogenic assays, $2 \times 10^{4}$ cells were plated in $250 \mathrm{ml}$ cell culture flasks. After stimulation they were treated with $5 \mu \mathrm{M}$ CDDP for three days. The media were changed daily.

\section{MTT- assay}

Cell viability was evaluated by MTT-assays using the tetrazolium salt method. The MTT-assay is a quantitative colorimetric method used to determine metabolic activity [27]. After three days of CDDP treatment, $10 \mu \mathrm{lof} 5 \mathrm{mg} / \mathrm{ml}$ MTT salt (in DMEM/F12 (PAA) supplemented with 10\% FBS (PAA), $2 \mathrm{mM}$ l-glutamine, 100 units $/ \mathrm{ml}$ penicillin, 
and $100 \mu \mathrm{g} / \mathrm{ml}$ streptomycin) was administered to the cells $(100 \mu \mathrm{l})$. Cells were incubated for $4 \mathrm{~h}$ at $37^{\circ} \mathrm{C}$ and then the formazan reaction product was dissolved using $10 \%$ sodium dodecylsulphate in $10 \mathrm{mM} \mathrm{HCl}$ at $37^{\circ} \mathrm{C}$ for 12 hours. Absorbance at $550 \mathrm{~nm}$ was measured with a microtiter plate reader (Athos 2010, Salzburg, Austria). The MTT-tests were performed in four independent sets containing at least six biological repeats.

\section{Clonogenic assay}

For analysis of the anti-clonogenic effect of CDDP on the tumor cells we used the modified clonogenic assay described by Phuk and coworkers [14]. SCC-25/ Detroit 562 cells were washed with PBS and cultured in $250 \mathrm{ml}$ tissue culture flasks in DMEM/F12 (PAA) supplemented with 10\% FBS (PAA), 2 mM l-glutamine, 100 units/ $\mathrm{ml}$ penicillin, and $100 \mu \mathrm{g} / \mathrm{ml}$ streptomycin for 14 days. After 14 days, cultures were fixed and stained in $0.5 \%$ gentian violet dissolved in methanol. Subsequently, the stained flasks were scanned in 1200 dpi resolution using a commercial flatbed scanner. Based on the resulting micrographs, colonies were counted and occupied areas were measured semi-automatically using a macro written in imageJ/FIJI macro language [28]. Background subtraction was performed on single images using rollingball-algorithm [29]. Micrographs were subjected to color deconvolution [30] and filtered using a Fourier band-pass filter. Colonies were segmented using auto-thresholding algorithms [31-35]. Segmented colonies were counted and occupied areas were measured. The clonogenic assays were performed in three independent sets.

\section{Data analysis}

Data were presented as mean $+/$ - standard deviation (SD) unless indicated otherwise. The $\mathrm{IC}_{50}+/-95 \%$ confidence intervals (CI) of CDDP were calculated with four-parameter nonlinear logistic regression using CurveExpert Professional (Daniel Hyams, Hixson, TN, USA). The results of real time PCR analysis were analyzed with GraphPad Prism 4.03 (GraphPad Software Inc, San Diego, CA, USA). Mean values among groups were compared with unpaired $t$-tests. MTT-changes in coculture conditioned medium treated cells vs. controls were tested with unpaired $t$-test. For evaluation of clonogenic assays, a two-factorial analysis of variance with colony number as the response parameter was used. Cell culture medium (co-culture vs. standard) and CCDP exposure $(0$ $\mu \mathrm{M}$ vs $5 \mu \mathrm{M}$ or $10 \mu \mathrm{M})$ served as factors. The interaction term served to indicate cell-culture mediated differences in CDDP sensitivity. For this data analysis, SPSS 22 was used (IBM Corporation, Armonk, NY, USA)

\section{CONFLICTS OF INTEREST}

The authors declare that they have no competing interests

\section{GRANT SUPPORT}

This work was supported by Austrian Science Fund [FWF P 25869-B13]. Role of the Funding Source: The funding source has no influence on the direction and the outcome of the study, it is an independent granting.

\section{REFERENCES}

1. Dudas J, Bitsche M, Schartinger V, Falkeis C, Sprinzl GM, Riechelmann H. Fibroblasts produce brain-derived neurotrophic factor and induce mesenchymal transition of oral tumor cells. Oral oncology. 2011;47:98-103.

2. Radisky DC. Fibroblasts act as co-conspirators for chemotherapy resistance. Cancer biology \& therapy. 2008;7:1348-9.

3. Smith A, Teknos TN, Pan Q. Epithelial to mesenchymal transition in head and neck squamous cell carcinoma. Oral oncology. 2013;49:287-92.

4. Orimo A, Weinberg RA. Stromal fibroblasts in cancer: a novel tumor-promoting cell type. Cell cycle. 2006;5:1597601.

5. Fullar A, Kovalszky I, Bitsche M, Romani A, Schartinger VH, Sprinzl GM, Riechelmann H, Dudas J. Tumor cell and carcinoma-associated fibroblast interaction regulates matrix metalloproteinases and their inhibitors in oral squamous cell carcinoma. Experimental cell research. 2012;318:1517-27.

6. Xu LN, Xu BN, Cai J, Yang JB, Lin N. Tumor-associated fibroblast-conditioned medium promotes tumor cell proliferation and angiogenesis. Genetics and molecular research : GMR. 2013;12:5863-71.

7. Katsuno Y, Lamouille S, Derynck R. TGF-beta signaling and epithelial-mesenchymal transition in cancer progression. Current opinion in oncology. 2013;25:76-84.

8. Dudas J, Fullar A, Romani A, Pritz C, Kovalszky I, Hans Schartinger V, Sprinzl GM, Riechelmann H. Curcumin targets fibroblast-tumor cell interactions in oral squamous cell carcinoma. Experimental cell research. 2013;319:800-9.

9. Rheinwald JG, Beckett MA. Tumorigenic keratinocyte lines requiring anchorage and fibroblast support cultured from human squamous cell carcinomas. Cancer research. 1981;41:1657-63.

10. Chen YW, Lin GJ, Chia WT, Lin CK, Chuang YP, Sytwu HK. Triptolide exerts anti-tumor effect on oral cancer and KB cells in vitro and in vivo. Oral oncology. 2009;45:562-8.

11. Sano D, Xie TX, Ow TJ, Zhao M, Pickering CR, Zhou G, Sandulache VC, Wheeler DA, Gibbs RA, Caulin C, Myers JN. Disruptive TP53 mutation is associated with aggressive disease characteristics in an orthotopic murine model of oral 
tongue cancer. Clinical cancer research. 2011;17:6658-70.

12. Peterson WD, Jr., Stulberg CS, Simpson WF. A permanent heteroploid human cell line with type B glucose-6phosphate dehydrogenase. Proceedings of the Society for Experimental Biology and Medicine Society for Experimental Biology and Medicine. 1971;136:1187-91.

13. Peterson WD, Jr., Stulberg CS, Swanborg NK, Robinson AR. Glucose-6-phosphate dehydrogenase isoenzymes in human cell cultures determined by sucrose-agar gel and cellulose acetate zymograms. Proceedings of the Society for Experimental Biology and Medicine Society for Experimental Biology and Medicine. 1968;128:772-6.

14. Puck TT, Marcus PI. Action of x-rays on mammalian cells. The Journal of experimental medicine. 1956;103:653-66.

15. Paraiso KH, Smalley KS. Fibroblast-mediated drug resistance in cancer. Biochemical pharmacology. 2013;85:1033-41.

16. Buchmaier BS, Bibi A, Muller GA, Dihazi GH, Eltoweissy M, Kruegel J, Dihazi H. Renal cells express different forms of vimentin: the independent expression alteration of these forms is important in cell resistance to osmotic stress and apoptosis. PloS one. 2013;8:e68301.

17. Dudas J, Fullar A, Bitsche M, Schartinger V, Kovalszky I, Sprinzl GM, Riechelmann H. Tumor-produced, active interleukin-1beta regulates gene expression in carcinomaassociated fibroblasts. Experimental cell research. 2011;317:2222-9.

18. Hassona Y, Cirillo N, Heesom K, Parkinson EK, Prime SS. Senescent cancer-associated fibroblasts secrete active MMP-2 that promotes keratinocyte dis-cohesion and invasion. British journal of cancer. 2014;111:1230-7.

19. Liu Y, Zhang M, Qian J, Bao M, Meng X, Zhang S, Zhang L, Zhao R, Li S, Cao Q, Li P, Ju X, Lu Q, et al. miR-134 Functions as a Tumor Suppressor in Cell Proliferation and Epithelial-to-Mesenchymal Transition by Targeting KRAS in Renal Cell Carcinoma Cells. DNA and cell biology. 2015.

20. Martin D, Abba MC, Molinolo AA, Vitale-Cross L, Wang Z, Zaida M, Delic NC, Samuels Y, Lyons JG, Gutkind JS. The head and neck cancer cell oncogenome: a platform for the development of precision molecular therapies. Oncotarget. 2014;5:8906-23.

21. Flach EH, Rebecca VW, Herlyn M, Smalley KS, Anderson AR. Fibroblasts contribute to melanoma tumor growth and drug resistance. Molecular pharmaceutics. 2011;8:2039-49.

22. Niessner H, Forschner A, Klumpp B, Honegger JB, Witte M, Bornemann A, Dummer R, Adam A, Bauer J, Tabatabai G, Flaherty K, Sinnberg T, Beck D et al. Targeting hyperactivation of the AKT survival pathway to overcome therapy resistance of melanoma brain metastases. Cancer medicine. 2013;2:76-85.

23. Bartling B, Hofmann HS, Silber RE, Simm A. Differential impact of fibroblasts on the efficient cell death of lung cancer cells induced by paclitaxel and cisplatin. Cancer biology \& therapy. 2008;7:1250-61.

24. Gilbert LA, Hemann MT. DNA damage-mediated induction of a chemoresistant niche. Cell. 2010;143:355-66.

25. Docheva D, Padula D, Popov C, Weishaupt P, Pragert M, Miosge N, Hickel R., Bocker W., Clausen-Schaumann H., Schieker M. Establishment of immortalized periodontal ligament progenitor cell line and its behavioural analysis on smooth and rough titanium surface. European cells \& materials. 2010;19:228-41.

26. Goutelle S, Maurin M, Rougier F, Barbaut X, Bourguignon L, Ducher M, Maire P. The Hill equation: a review of its capabilities in pharmacological modelling. Fundamental \& clinical pharmacology. 2008;22:633-48.

27. Schartinger VH, Galvan O, Riechelmann H, Dudas J. Differential responses of fibroblasts, non-neoplastic epithelial cells, and oral carcinoma cells to low-level laser therapy. Supportive care in cancer. 2012;20:523-9.

28. Schindelin J, Arganda-Carreras I, Frise E, Kaynig V, Longair M, Pietzsch T, Preibisch S, Rueden C, Saalfeld S, Schmid B, Tinevez JY, White DJ, Hartenstein V, et al. Fiji: an open-source platform for biological-image analysis. Nature methods. 2012;9:676-82.

29. Sternberg B. Exploring the potential of computer-assisted medical illustration. Biomedical communications. 1983;11:28-31.

30. Ruifrok AC, Johnston DA. Quantification of histochemical staining by color deconvolution. Analytical and quantitative cytology and histology / the International Academy of Cytology [and] American Society of Cytology. 2001;23:291-9.

31. Zack GW, Rogers WE, Latt SA. Automatic measurement of sister chromatid exchange frequency. The journal of histochemistry and cytochemistry. 1977;25:741-53.

32. Li CH, Lee C.K. . Minimum Croos Entropy Thresholding. Pattern Recognition. 1993;26:617-25.

33. Kapur JN, Sahoo PK, Wong AKC. A new method for gray-level picture thresholding using the entropy of the histogram. Computer Vision, Graphics, and Image Processing. 1985;29:273-85.

34. N. O. A treshold Selection Method from Gray-Level Histograms. IEEE Transactions on Systems, Man, and Cybernetics. 1979;1:62-6.

35. Shanbhag AG. Utilization of Information Measure as a Means of Image Thresholding. CVGIP: Graphical Models and Image Processing. 1994;56:414-9. 